\title{
Galactokinase Deficiency
}

National Cancer Institute

\section{Source}

National Cancer Institute. Galactokinase Deficiency. NCI Thesaurus. Code C114767.

An autosomal recessive disorder caused by mutations in the GALK1 gene. The disorder is characterized by an accumulation of galactose and galactitol secondary to the decreased conversion of galactose to galactose-1-phosphate by galactokinase. Its major clinical symptom is the development of cataracts during the first weeks or months of life. 